NBER WORKING PAPER SERIES

\title{
THE IMPACT OF INTERGENERATIONAL TRANSFERS ON HOUSEHOLD WEALTH INEQUALITY IN JAPAN AND THE UNITED STATES
}

\author{
Yoko Niimi \\ Charles Yuji Horioka \\ Working Paper 22687 \\ http://www.nber.org/papers/w22687 \\ NATIONAL BUREAU OF ECONOMIC RESEARCH \\ 1050 Massachusetts Avenue \\ Cambridge, MA 02138 \\ September 2016
}

The empirical work undertaken in this paper utilizes micro data from the Preference Parameters Study of Osaka University's 21st Century COE Program "Behavioral Macrodynamics Based on Surveys and Experiments' and its Global COE Project 'Human Behavior and Socioeconomic Dynamics." We acknowledge the program/project's contributors Yoshiro Tsutsui, Fumio Ohtake and Shinsuke Ikeda. We are also grateful to Tomoki Fujii, Tatsuo Hatta, Matthias Helble, Richard Cheung Lam, Kang H. Park, Eric Ramstetter, Dylan Rassier, Ayako Saiki, Tien Mahn Vu, Guanghua Wan, Naoyuki Yoshino, Eden Yu, and other participants of the 11th Biennial ACFEA (Asian Consumer and Family Economics Association) Conference, the Asian Development Bank Institute-World Economy Workshop on Sources of Income Inequality in Asia, a seminar at the Asian Growth Research Institute, and the 34th IARIW (International Association for Research in Income and Wealth) General Conference. This work was supported by JSPS (Japan Society for the Promotion of Science) KAKENHI Grant Number 15H01950, a project grant from the Asian Growth Research Institute, and a grant from the MEXT Joint Usage/Research Center at the Institute of Social and Economic Research, Osaka University. The views expressed herein are those of the authors and do not necessarily reflect the views of the National Bureau of Economic Research.

NBER working papers are circulated for discussion and comment purposes. They have not been peer-reviewed or been subject to the review by the NBER Board of Directors that accompanies official NBER publications.

(C) 2016 by Yoko Niimi and Charles Yuji Horioka. All rights reserved. Short sections of text, not to exceed two paragraphs, may be quoted without explicit permission provided that full credit, including $\odot$ notice, is given to the source. 
The Impact of Intergenerational Transfers on Household Wealth Inequality in Japan and the United States

Yoko Niimi and Charles Yuji Horioka

NBER Working Paper No. 22687

September 2016

JEL No. D10,D31,D64,E21,I24

\begin{abstract}
$\underline{\text { ABSTRACT }}$
To help shed light on the implications of intergenerational transfers for wealth inequality, this paper examines whether or not individuals who receive intergenerational transfers from their parents are more likely to leave bequests to their children than those who do not using data for Japan and the United States. The estimation results show that the receipt of intergenerational transfers from parents and/or parents-in-law increases the likelihood of individuals' leaving bequests to their own children in both Japan and the United States, which in turn is likely to contribute to the persistence or widening of wealth disparities. However, such a tendency is found to be stronger among less better-off households in both countries, and this may help alleviate the disequalizing effect of intergenerational transfers on the distribution of wealth, at least to some extent.
\end{abstract}

Yoko Niimi

Asian Growth Research Institute

11-4, Ohtemachi, Kokurakita-ku

Kitakyushu City, Fukuoka 803-0814

Japan

niimi@agi.or.jp

Charles Yuji Horioka

Asian Growth Research Institute

11-4, Ohtemachi, Kokurakita-ku

Kitakyushu City, Fukuoka 803-0814

Japan

and NBER

horioka@iser.osaka-u.ac.jp 


\section{Introduction}

It is widely recognized that household wealth is distributed less equally than income or consumption expenditure (Davies and Shorrocks, 2000). Among the Organisation for Economic Co-operation and Development (OECD) member countries, it is estimated that the wealthiest $10 \%$ of households hold, on average, about half of total wealth, the next $50 \%$ hold almost all of the other half, and the least wealthy $40 \%$ hold little over $3 \%$ whereas their share of total household income is about 20\% (OECD, 2015). ${ }^{1}$ Wealth inequality has attracted increased attention recently as the latest studies show that wealth inequality has been rising in recent decades (e.g., Piketty, 2014; Saez and Zucman, 2016). Saez and Zucman (2016), for example, show that in the case of the US, wealth concentration fell from 1929 to 1978 but has been increasing since then: the top $0.1 \%$ wealth share has risen from 7\% in 1978 to 22\% in 2012, a level almost as high as in 1929.

Household wealth arises primarily from life-cycle saving or from transfers from others, including bequests and inter vivos transfers from one's parents (hereafter referred to collectively as intergenerational transfers). One of the most disputed topics in this area is the relative importance of intergenerational transfers vis-à-vis life-cycle saving as determinants of the level and distribution of wealth. ${ }^{2}$ According to the life-cycle hypothesis, individuals save (accumulate wealth) during their working years to finance consumption after retirement and dissave during old age (Modigliani and Brumberg, 1954). However, because of uncertain lifetimes and precautionary saving for unforeseen income or health shocks, the dissaving rate among retirees is found to be lower than suggested by the life-cycle hypothesis, and as a result, a positive amount of wealth is left unconsumed and passed onto the next generation as inheritance (Davies, 1981; Yaari,

\footnotetext{
${ }^{1}$ The calculations are based on data for 18 OECD member countries for which comparable data were available (OECD, 2015).

${ }^{2}$ For example, Kotlikoff and Summers (1981) estimate that private transfers of wealth across generations account for about $80 \%$ of current wealth while Modigliani (1988) claims that at least $80 \%$ of total wealth is due to life-cycle accumulation. The significant discrepancy between these two estimates arises largely from whether household expenditure on durable goods is treated as consumption or saving, whether the accrued interest on transfers is attributed to life-cycle accumulation or inherited wealth, and whether parental support for dependent children over the age of 18 is treated as consumption or a form of bequest (Modigliani, 1988).
} 
1965).

In addition to these unintended or accidental transfers, some individuals save in order to leave bequests to the next generation. Indeed, it has been pointed out that the extreme upper tail of the wealth distribution cannot be explained by the life-cycle hypothesis alone, which suggests the importance of a bequest motive in the wealth accumulation process (e.g., Atkinson, 1971; Oulton, 1976). After reviewing the existing work on the relative importance of intergenerational transfers, Davies and Shorrocks (2000) conclude that a reasonable estimate of their contribution to aggregate wealth is about 35-45\%. More recently, Piketty (2011) points out that the importance of inheritance has been on the rise in France since the 1950s with an acceleration of the trend during the past 30 years. Intergenerational transfers are thus likely to play an important role in determining the wealth accumulation process. However, whether such transfers enhance or reduce wealth inequality remains unresolved as different conclusions are reached by different studies, even though it is an important question for policy makers when designing policies for tackling inequality.

The main objective of this paper is to contribute to a better understanding of the role of intergenerational transfers in shaping the distribution of wealth. While there are various ways to examine the implications of intergenerational transfers for wealth inequality, this paper looks specifically at whether or not individuals who receive bequests and/or inter vivos transfers from their parents are more likely to pass their wealth onto their children than those who do not receive such transfers. If we observe similarities in bequest behavior between parents and children, wealth disparities are likely to be passed on from generation to generation. This would, in turn, contribute to the persistence or widening of wealth disparities, which might be a greater concern than the extent of wealth inequality at a given point in time.

Unfortunately, empirical evidence on the patterns of bequest behavior across generations remains scarce, presumably due to data limitations. This paper therefore attempts to fill this gap in the literature by analyzing the intergenerational correlation of bequest 
propensities in the cases of Japan and the United States (US). As recent estimates show that wealth inequality is much greater in the US (Gini coefficient for wealth of 0.801 ) than in Japan (0.547) (Davies et al., 2011), ${ }^{3}$ it would be interesting to see whether we observe any differences in the intergenerational correlation of bequest propensities between these two countries. The data used in this paper come from the "Preference Parameters Study” of Osaka University, a nationally representative survey conducted concurrently in four countries, namely China, India, Japan, and the US, over the 20032013 period (though for shorter periods for some countries). Given that these data contain detailed information on respondents' bequest receipts as well as their bequest plans, they are well-suited for examining the intergenerational correlation of bequest propensities, and this paper makes an original contribution by being one of the first papers to do so.

The key hypotheses that this paper tests are as follows: (i) individuals who receive intergenerational transfers tend to come from better-off families, (ii) individuals who receive intergenerational transfers are more likely to leave their wealth to their own children, and (iii) the tendency for bequest behavior to be similar between parents and children is stronger among better-off households. If these hypotheses hold, we can argue that intergenerational transfers are likely to contribute to the persistence or widening of wealth disparities over time.

The rest of the paper is organized as follows. Section 2 reviews the literature on the impact of intergenerational transfers on wealth inequality. Section 3 discusses the data, the econometric methodology, and the variables used in the estimations. Estimation results are presented in Section 4. Section 5 summarizes the key findings and discusses some policy implications.

\footnotetext{
3 The US and Japan are at opposite extremes with respect to wealth inequality, with the US having the highest wealth Gini coefficient with the exception of Switzerland and Japan having the lowest wealth Gini coefficient of any country for which data are available, according to Davies et al. (2011).
} 


\section{Literature Review}

Whether intergenerational transfers have an equalizing or disequalizing effect on the distribution of wealth remains unresolved as no consensus has been reached by existing studies. One approach to assessing the impact of intergenerational transfers on wealth inequality is to simulate the transmission of inequality via bequests. For example, based on a one-period intragenerational model that incorporates bequest motives, Davies (1982) finds a disequalizing effect of bequests on current wealth, especially in the upper tail of the distribution, largely because of the high income elasticity of bequests.

Similar findings are obtained by De Nardi (2004) based on a general equilibrium, overlapping-generations model where parents and children are linked by bequests, both voluntary and accidental, and by the transmission of earnings ability. She finds that voluntary bequests can explain the concentration of wealth while accidental bequests alone cannot and that adding the transmission of earnings ability from parents to children generates an even more concentrated wealth distribution. She also finds that saving for precautionary purposes as well as for retirement is the primary cause of wealth accumulation at the lower tail of the distribution while saving for bequests significantly affects the shape of the upper tail (De Nardi, 2004).

While voluntary bequests are not taken into account in their overlapping generations model with uncertain lifespan, Gokhale et al. (2001) find that unintended bequests also exacerbate wealth inequality in the presence of social security, which disproportionately disinherits the lifetime poor. Their simulation results suggest that the key determinants of wealth inequality aside from social security include inequality in lifetime earnings (skill differences), assortative mating based on skills, and the degree of time preference.

On the other hand, based on their overlapping generations model, Bossmann, Kleiber and Wälde (2007) show analytically that intergenerational transfers per se diminish the inequality of wealth when it is measured using the coefficient of variation. The main reason for the equalizing effect of intergenerational transfers is that such transfers raise 
private saving and thus average wealth holdings and that this effect is large enough to compensate for the increase in the variance of wealth caused by intergenerational transfers.

As for empirical evidence based on survey data, intergenerational transfers are commonly found to make the distribution of wealth more equal. Based on Swedish household survey data, Klevmarken (2004) finds that bequests decrease wealth inequality mainly because parents tend to split their wealth equally among their children, because wealth is transferred from wealthy parents to less wealthy children, and because even though less wealthy people receive smaller bequests they mean relatively more to them. However, Klevmarken (2004) also points out that the very accumulation of wealth for the purpose of leaving bequests is likely to increase wealth inequality--i.e., the bequest motive increases inequality while actual transfers to children decrease it.

Using data on the US, Wolff (2002) also finds that wealth transfers are greater for poorer households than for richer ones as a proportion of their current wealth holdings--i.e., "a small gift to the poor means more than a large gift to the rich” (Wolff, 2002: 263). Yet, Wolff (2002) argues that the equalizing effect of intergenerational transfers does not imply from a behavioral point of view that such transfers lead to less wealth inequality since the poor are prone to spend their (meager) inheritances while the rich are likely to save them. Similarly, Karagiannaki (2015) finds for the United Kingdom that, under a relative notion of inequality, intergenerational transfers reduce the degree of wealth dispersion because they are relatively more important to less wealthy households. Nevertheless, intergenerational transfers are highly unequal and their size tends to be greater for those with higher non-inherited wealth, which, in turn, results in widening absolute gaps in the wealth distribution (Karagiannaki, 2015).

Using population-wide register data on inheritances and wealth in Sweden, Elinder, Erixson and Waldenström (2016) also find that inheritances reduce relative inequality but increase the absolute dispersion of wealth. Such a discrepancy between relative and absolute effects arises because, while wealthier individuals inherit larger amounts, less 
wealthy individuals receive much larger inheritances relative to their pre-inheritance wealth. In addition to this direct effect of inheritances, Elinder, Erixson and Waldenström (2016) examine the behavior-adjusted effect of inheritances, which captures the behavioral change of heirs in response to the receipt of inheritances. They find that less wealthy heirs tend to consume a larger share of their inherited wealth than wealthier heirs and that these behavioral adjustments, in turn, dilute the equalizing impact of inheritances.

If the rich are more likely than the poor to save their inheritances instead of spending them, as noted by Wolff (2002) and Elinder, Erixson and Waldenström (2016), we may observe a higher correlation between the bequest propensities of parents and children among wealthy households than among less wealthy households. While there are a number of studies that examine the degree of correlation between the level of parents' wealth and that of children's wealth (i.e., intergenerational wealth mobility) (e.g., Charles and Hurst, 2003), there has been very limited work that examines the intergenerational correlation of bequest propensities.

The few exceptions include Cox and Stark (2005), Niimi (2016), and Horioka (2016). Cox and Stark (2005) find a positive and significant effect of the receipt of inheritances on intended bequest behavior even after controlling for a host of factors commonly implicated in bequest behavior based on data for the US. Niimi (2016) examines the behavioral response of households to a reduction in the basic deduction of the inheritance tax in Japan. She finds that households that have received or expect to receive bequests and/or inter vivos transfers from their parents are more likely to reallocate the newly taxable amount of wealth to inter vivos transfers to avoid an increase in their children's tax bill in comparison with those not receiving such transfers. This suggests that households who receive bequests from their parents may regard the bequests as the wealth of their family and feel obliged to pass it on to their children. Finally, Horioka (2016) finds using the same data source as the one used in this paper that those who received or expect to receive intergenerational transfers from their parents are more likely to leave bequests to their own children than those who did not receive or do not expect to receive such transfers from their parents in Japan, the US, and China but not in India and that the 
gap in bequest propensities between the two groups is largest in Japan. However, he simply compares averages and does not conduct an econometric analysis.

This paper aims to extend the literature by conducting a comparative analysis of the intergenerational correlation of bequest propensities in Japan and the US. It would be interesting to see whether we observe any differences in the intergenerational correlation of bequest propensities between these two countries with very different levels of wealth inequality (wealth inequality is much greater in the US than in Japan, as noted earlier). Moreover, this paper will assess whether the intergenerational correlation of bequest propensities differs at different points of the wealth distribution. It will therefore specifically test the following three hypotheses: (i) individuals who receive intergenerational transfers tend to come from better-off families, (ii) individuals who receive intergenerational transfers are more likely to leave their wealth to their own children, and (iii) the tendency for bequest behavior to be similar between parents and children is stronger among better-off households. If these three hypotheses hold, we can argue that intergenerational transfers are likely to contribute to the persistence or widening of wealth disparities across households.

Due to the absence of information on the amount of intergenerational transfers that respondents have received from their parents and/or parents-in-law in our data source, it was not possible to estimate the magnitude of the contribution of intergenerational transfers to wealth inequality in this paper. This paper focuses instead on analyzing the intergenerational correlation of bequest propensities. Nonetheless, the findings from such an analysis can still contribute to enhancing our understanding of the role of intergenerational transfers in shaping the distribution of wealth by providing a directional indication of the possible impact of intergenerational transfers on wealth inequality. 


\section{Data and Methodology}

\subsection{Data}

The empirical analysis will be conducted using data from the "Preference Parameters Study” of Osaka University, which was conducted in Japan and the US by the $21^{\text {st }}$ Century Center of Excellence (COE) Program "Behavioral Macrodynamics Based on Surveys and Experiments" and the Global COE Project "Human Behavior and Socioeconomic Dynamics” of Osaka University. This survey was undertaken with the aim of examining whether the assumptions of conventional economics that people are rational and maximize utility are valid.

The Japanese survey was conducted annually during the 2003-2013 period using a randomly selected nationally representative sample of individuals aged 20-69. The survey has a panel component although fresh observations were added in 2004, 2006, and 2009 to overcome the problem of attrition.

The US survey was conducted annually during the 2005-2013 period using an almost identical survey instrument. The US sample was selected to be representative of individuals aged 18 and above in the continental US (i.e., all states except for Alaska and Hawaii). While fresh observations were added in 2007, 2008, 2009, and 2013, the US survey also has a panel component.

It would have been ideal to conduct a panel data analysis to take into account individual fixed effects, but unfortunately questions regarding the receipt of bequests as well as bequest plans were not included in every wave and the wording of some of the key questions differed between waves. The empirical analysis in this paper is thus undertaken using only data from the 2010 wave. The 2010 wave was selected largely because it has a relatively large sample size for both Japan and the US and because it contains all of the key information needed for the present analysis. 
In the case of the 2010 wave, 5,386 respondents and 6,003 respondents completed the questionnaire in Japan and the US, respectively. ${ }^{4}$ After excluding observations without any children and with missing information on the variables used in our analysis, we were left with 2,914 and 1,997 observations for Japan and the US, respectively.

In addition to basic information on respondents and their households such as household composition, consumption, income, wealth, and other socio-economic characteristics, this survey contains information on respondents' (expected) receipt of bequests and inter vivos transfers from their parents and parents-in-law as well as their bequest plans. The survey also contains unique information including the education level of respondents' parents, the relative standard of living of respondent's families when respondents were 15 years old, and respondents' preference parameters, such as their degree of time preference, risk aversion, and altruism. By exploiting this rich dataset, it is possible to test the key hypotheses outlined above.

\subsection{Methodology}

To test the hypotheses outlined at the end of Section 2, we will conduct two regression analyses. The first analysis examines whether individuals who receive intergenerational transfers tend to come from better-off families. In other words, we investigate whether having wealthier parents increases the likelihood of receiving intergenerational transfers. In doing so, we take into account the possibility that parents may not only provide bequests and/or inter vivos transfers to their children but that they may also invest in the human capital of their children, as the previous literature suggests (e.g., Becker and Tomes, 1986; Nordblom and Ohlsson, 2011). We therefore estimate a seemingly unrelated bivariate probit model that accounts for correlation between the two kinds of transfers, namely education and bequests and/or inter vivos transfers.

\footnotetext{
${ }^{4}$ While 7,046 respondents completed the questionnaire in the US, this sample includes 1,043 observations that were accidentally answered by unintended household members and their inclusion in the sample was not recommended.
} 
The second analysis examines whether the receipt of intergenerational transfers increases individuals’ likelihood of leaving bequests to their own children. ${ }^{5}$ It also investigates whether or not such a correlation is greater among better-off households. Toward this end, we estimate a probit model for the probability of leaving bequests to one's children, regress it on, among others, the (expected) receipt of intergenerational transfers, and interact this variable with the wealth variables.

\subsection{Empirical Specification}

\section{(1) Determinants of the receipt of intergenerational transfers}

Dependent variables: The dependent variables of the bivariate probit model are (i) a dummy variable that equals one if respondents obtained a university or higher degree and zero otherwise and (ii) a dummy variable that equals one if respondents received or expect to receive bequests and/or inter vivos transfers from their own parents and zero otherwise. The former is a proxy for parents' investment in respondents' education while the latter is an indicator of financial/property transfers from parents to respondents. ${ }^{6}$

Explanatory variables: Given that we do not have information on the income or wealth level of respondents’ parents, we use parents' educational attainment as one of two proxies therefor. We include variables that indicate the number of years of schooling of respondents' fathers and mothers. We would expect that the more highly educated parents are, the more likely their children are to have a university or higher degree and the more likely their children are to receive bequests and/or inter vivos transfers. The former could imply that wealthier (more highly educated) parents are more likely to invest in the human

\footnotetext{
5 Due to the absence of information on the educational attainment of respondents' children, we could only investigate respondents' bequest behavior in this part of the analysis, leaving an analysis of their investment in the human capital of their own children as an agenda for future research.

6 Since we did not have any information on how respondents' university education expenses were financed, we had no choice but to assume that parents paid for at least a portion of respondents' university education expenses, but this does not seem like an unrealistic assumption given that it is highly unlikely that university education expenses were financed completely by scholarships, educational loans, part-time work, and/or respondents' own resources with no financial assistance from parents.
} 
capital of their children, but it could also simply reflect the transmission of abilities from parents to children. Unfortunately, we cannot distinguish between these two possibilities in the present analysis due to data limitations.

As another proxy for how prosperous respondents' parents are/were, we also include a variable that indicates the relative standard of living of respondents' families when they were 15 years old. ${ }^{7}$ Respondents were asked to indicate their relative standard of living during their childhood on a scale of $0-10$ with " 10 ” being "wealthiest" and " 0 ” being "poorest," and we treat this variable as being cardinal.

We also control for the number of siblings respondents have. The survey we use collects information on both the number of siblings respondents had when they were 15 years old and the number of siblings respondents currently have. To reflect as closely as possible the number of children that respondents' parents had when they made/make decisions with respect to the education of their children as well as the provision of bequests to their children, we use the former measure in the education equation and the latter measure in the bequest equation in the bivariate probit model. ${ }^{8}$ If parents have a larger number of children, their resources are likely to be stretched to a greater extent and the amount of resources available per child is likely to be smaller. We would therefore expect these variables to lower the probability of respondents' having a university or higher degree and that of respondents receiving or expecting to receive bequests and/or inter vivos transfers, respectively.

In addition to the aforementioned variables, we include variables that reflect the age, gender, marital status, and (in the case of the US sample) race of respondents as well as regional dummies.

\footnotetext{
7 We obtained the information on the relative standard of living of respondents' families when they were 15 years old from the 2009 wave of the Preference Parameters Study as such information was not available in the 2010 wave.

${ }^{8}$ We obtained the information on the number of siblings that respondents had when they were 15 years old from the 2009 wave of the Preference Parameters Study as such information was not available in the 2010 wave.
} 


\section{(2) Determinants of bequest intentions}

Dependent variable: The dependent variable of the probit model is a dummy variable that equals one if respondents intend to leave bequests to their own children and zero otherwise. The Preference Parameters Study asked respondents about their view toward leaving bequests to their children, and the dependent variable takes a value of one if respondents plan to leave bequests no matter what, if they plan to leave bequests under certain conditions (e.g., if their children provide care or financial assistance during old age or carry on the family business), or if they do not plan to make special efforts to leave bequests but plan to leave whatever is left over. ${ }^{9}$ In other words, this variable takes a value of one if respondents are likely to leave bequests to their children, regardless of the reason for leaving bequests.

Explanatory variables: Our main variable of interest is whether or not respondents have received or expect to receive intergenerational transfers from their own parents and/or parents-in-law. We would expect the receipt of intergenerational transfers to increase the probability of respondents' leaving bequests to their own children. To see whether such an effect is greater among wealthier households, we include variables that indicate the wealth level of respondents' household and interact them with the variable for the (expected) receipt of intergenerational transfers. Our wealth variables are expressed as quintiles of net worth, defined as the total amount of financial and non-financial assets net of liabilities. To account for age differences in wealth accumulation, the quintiles are defined separately for five age groups. ${ }^{10}$

We include a variable that indicates the average number of years of schooling of respondents and their spouses (the number of years of schooling of respondents in the

\footnotetext{
9 Because of uncertain lifetimes and precautionary saving for unforeseen income or health shocks, respondents are likely to leave a positive amount of bequests if they say that they will leave whatever wealth is left over to their children.

10 The age groups used were (i) less than 35, (ii) 35-44, (iii) 45-54, (iv) 55-64, and (v) 65 years old or above, and the age of the respondent or (if the respondent is married) the average age of the respondent and his or her spouse was used.
} 
case of unmarried respondents) to proxy for the permanent income of respondents' households. We would expect that the better off (more highly educated) respondents and their spouses are, the more likely they will be to leave bequests to their own children.

To control for the unobserved time-invariant characteristics of respondents, we construct variables that can serve as proxies for their degree of altruism toward their children, time preference, and risk aversion using the best available data in our data source. Our measure of the degree of altruism toward one's children is constructed using responses to a hypothetical question asking respondents to indicate how much of their family income they are willing to give to their children until the situation gets better if their children (who do not live with them) had only one-third of respondents' per capita family income. As for the degree of time preference, it is constructed using responses to a question about whether or not respondents generally prefer getting their work done before having a good time. Our measure of the degree of risk aversion is constructed using responses to a question asking respondents to rate their behavioral pattern on a scale of 0-10 with " 10 " being completely in agreement with the thinking "nothing ventured, nothing gained" and "0" being completely in agreement with the thinking of "a wise man never courts danger." We regard this variable as a proxy for the degree of risk aversion and treat it as cardinal.

In the case of empirical studies based on cross-sectional data, the problem of endogeneity arising from unobserved heterogeneity can be an issue. This study is no exception, but we cannot undertake a panel data analysis due to data limitations, as explained above. Instead, this problem will be addressed by including these proxy variables that reflect respondents' preference parameters so that at least some of the heterogeneity can be controlled for.

Other explanatory variables include the number of children respondents have, the age, gender, marital status, and (in the case of the US sample) race of respondents, and regional dummies. 


\section{Estimation Results}

\subsection{Descriptive Statistics}

Table 1 provides the summary statistics for the dependent and explanatory variables included in the estimations for both Japan and the US. In the case of Japan, about 26\% and $54 \%$ of respondents have a university or higher degree and have received or expect to receive bequests and/or inter vivos transfers from their parents, respectively. Both percentages are higher in the US (about 38\% and 63\%, respectively) than in Japan and the differences are statistically significant at the $1 \%$ level. ${ }^{11}$ As expected, we observe a positive correlation between the incidence of these two kinds of transfers (education and financial/property transfers), but the magnitude is relatively small (about $0.17(p=0.000)$ for both Japan and the US). As far as bequest behavior is concerned, the percentage of respondents who plan to leave bequests to their children is about 77\% in Japan, which is again smaller than in the US (about 87\%) and again this difference is statistically significant at the $1 \%$ level. Judging from these statistics, the incidence of intergenerational transfers appears to be generally greater in the US than in Japan.

Table 1. Summary Statistics

\begin{tabular}{|c|c|c|c|c|}
\hline & \multicolumn{2}{|c|}{ Japan } & \multicolumn{2}{|c|}{ US } \\
\hline & Mean & S.D. & Mean & S.D. \\
\hline \multicolumn{5}{|l|}{ Dependent variables } \\
\hline Have a university or higher degree & 0.26 & & 0.38 & \\
\hline Received or expect to receive bequests & 0.54 & & 0.63 & \\
\hline Intend to leave bequests to children & 0.77 & & 0.87 & \\
\hline \multicolumn{5}{|l|}{ Explanatory variables } \\
\hline \multicolumn{5}{|l|}{ Respondents' characteristics } \\
\hline \multicolumn{5}{|l|}{ Age group } \\
\hline Less than 35 & 0.07 & & 0.11 & \\
\hline $35-44$ & 0.22 & & 0.21 & \\
\hline $45-54$ & 0.26 & & 0.29 & \\
\hline $55-64$ & 0.28 & & 0.22 & \\
\hline $65+$ & 0.18 & & 0.18 & \\
\hline
\end{tabular}

11 However, the US-Japan gap in the proportion of respondents with a university or higher degree may exaggerate the US-Japan gap in the proportion of respondents receiving intergenerational transfers from their parents in the form of investment in human capital given the conventional wisdom that parents are less likely to contribute to their children's university education expenses in the US than in Japan. 


\begin{tabular}{|c|c|c|c|c|}
\hline & \multicolumn{2}{|c|}{ Japan } & \multicolumn{2}{|c|}{ US } \\
\hline & Mean & S.D. & Mean & S.D. \\
\hline \multicolumn{5}{|l|}{ Sex } \\
\hline Male & 0.48 & & 0.44 & \\
\hline Female & 0.52 & & 0.56 & \\
\hline \multicolumn{5}{|l|}{ Marital status } \\
\hline Married & 0.92 & & 0.79 & \\
\hline Divorced & 0.03 & & 0.08 & \\
\hline Widowed & 0.04 & & 0.05 & \\
\hline Never married & 0.01 & & 0.09 & \\
\hline \multicolumn{5}{|l|}{ Race } \\
\hline White & & & 0.84 & \\
\hline Black & & & 0.10 & \\
\hline Others & & & 0.06 & \\
\hline \multicolumn{5}{|l|}{ Preference parameters } \\
\hline Altruism toward children & 11.48 & 7.94 & 10.93 & 8.15 \\
\hline Low time preference & 0.46 & & 0.69 & \\
\hline Risk lover & 4.09 & 1.95 & 5.37 & 2.39 \\
\hline \multicolumn{5}{|l|}{ Family background } \\
\hline Fathers' education (years of schooling) & 11.01 & 2.42 & 12.48 & 2.66 \\
\hline Mothers' education (years of schooling) & 10.63 & 1.74 & 12.41 & 2.14 \\
\hline Living standard at the age of 15 & 4.68 & 1.85 & 4.32 & 1.97 \\
\hline Number of siblings (current) & 1.99 & 1.35 & 2.60 & 2.06 \\
\hline Number of siblings (at the age of 15) & 2.19 & 1.56 & 2.83 & 2.13 \\
\hline \multicolumn{5}{|l|}{ Respondents' household characteristics } \\
\hline Number of children & 2.14 & 0.75 & 2.46 & 1.30 \\
\hline $\begin{array}{l}\text { Average years of schooling } \\
\text { of respondent and (if married) spouse }\end{array}$ & 13.09 & 1.88 & 14.55 & 2.03 \\
\hline $\begin{array}{l}\text { (Expected) receipt of bequests from } \\
\text { parents and/or parents-in-law }\end{array}$ & 0.66 & & 0.70 & \\
\hline \multicolumn{5}{|l|}{ Wealth quintiles } \\
\hline $1^{\text {st }}$ quintile & 0.22 & & 0.21 & \\
\hline $2^{\text {nd }}$ quintile & 0.22 & & 0.20 & \\
\hline $3^{\text {rd }}$ quintile & 0.18 & & 0.19 & \\
\hline $4^{\text {th }}$ quintile & 0.19 & & 0.20 & \\
\hline $5^{\text {th }}$ quintile & 0.19 & & 0.20 & \\
\hline Number of observations & & & & \\
\hline
\end{tabular}

S.D. = standard deviation.

Source: Calculations based on data from the 2010 Preference Parameters Study.

The average age of respondents is slightly older than 50 years old, just over half of them are female, and the majority are married in both Japan and the US, though we observe greater heterogeneity in the marital status of respondents in the US than in Japan. As for preference parameters, both the Japanese and Americans express a similar degree of altruism toward their children - respondents would provide, on average, up to about $11 \%$ of their family income to their children if their children's income was about one-third of their own per capita family income. Americans appear to have a lower rate of time preference (place more emphasis on their well-being in the future than today) than the 
Japanese. On the other hand, the Japanese are found to be more risk averse than Americans.

Similar trends are observed in both countries with respect to respondents' family backgrounds although the number of years of schooling of respondents' parents and the number of siblings are both slightly larger in the US sample than in the Japanese one. As for respondents' household characteristics, the average number of children is about two for both samples whereas the average number of years of schooling of respondents and (if they are married) their spouses is again slightly larger among Americans than among the Japanese. The percentage of respondents who have received or expect to receive intergenerational transfers from their parents and/or parents-in-law is also greater for the US sample (about 70\%) than for the Japanese one (about 66\%) and the difference is statistically significant at the $1 \%$ level. This provides further corroboration of our earlier finding that bequest motives are stronger in the US than in Japan.

We find a positive correlation between the (expected) receipt of intergenerational transfers from parents and/or parents-in-law and the intention of leaving a bequest to one's own children for both countries, but the magnitude is again found to be relatively small (about $0.20(p=0.000)$ and $0.21(p=0.000)$ for Japan and the US, respectively). It is interesting to note that the correlation between the receipt of intergenerational transfers from parents and from parents-in-law is much lower among the Japanese (about 0.15 ( $p$ $=0.000)$ ) than among Americans (about $0.37(p=0.000)$ ). This could be an indication of a greater tendency toward assortative mating in the US than in Japan or it could reflect differences in social norms, with the Japanese being more likely to leave bequests to sons than to daughters, as we will show later in Table 4.

To investigate whether respondents who receive intergenerational transfers from their parents tend to come from better-off households (Hypothesis 1), Table 2 summarizes the percentage of respondents with a university or higher degree and the percentage of those who have received or expect to receive bequests and/or inter vivos transfers from their parents broken down by the educational attainment of their parents and the relative 
standard of living of respondents' families when they were 15 years old, both of which can be seen as proxies for the income or wealth level of respondents' parents. Note that educational attainment here refers to that of the respondent's father or mother, whichever is higher. The figures in Table 2 reveal that respondents' likelihood of obtaining a university or higher degree as well as their likelihood of receiving bequests and/or inter vivos transfers from their parents increase monotonically with the level of their parents' educational attainment and with their families' relative standard of living in both Japan and the US.

Table 2. Incidence of Intergenerational Transfers by Parents' Living Standard

\begin{tabular}{|c|c|c|c|c|}
\hline & \multicolumn{2}{|c|}{$\begin{array}{c}\text { \% of respondents with a } \\
\text { university or higher degree }\end{array}$} & \multicolumn{2}{|c|}{$\begin{array}{l}\text { \% of respondents who received } \\
\text { or expect to receive bequests }\end{array}$} \\
\hline & Japan & US & Japan & US \\
\hline \multicolumn{5}{|l|}{ Parents' educational attainment } \\
\hline Junior high school or lower & 14.01 & 21.64 & 47.54 & 52.05 \\
\hline High school & 28.36 & 30.77 & 59.17 & 60.03 \\
\hline Junior college & 43.10 & 36.63 & 62.07 & 67.23 \\
\hline University or higher & 56.80 & 68.87 & 60.53 & 74.06 \\
\hline \multicolumn{5}{|l|}{ Relative living standard } \\
\hline Relatively poor & 15.66 & 33.14 & 41.67 & 52.55 \\
\hline Average & 27.49 & 41.01 & 56.20 & 68.18 \\
\hline Relatively rich & 36.19 & 42.41 & 67.15 & 71.21 \\
\hline Full sample & 25.70 & 38.41 & 54.05 & 63.04 \\
\hline Number of observations & 2,914 & 1,997 & 2,914 & 1,997 \\
\hline
\end{tabular}

Similarly, Table 3 shows the percentage of respondents who have received or expect to receive intergenerational transfers from their parents and/or parents-in-law and the percentage of those who intend to leave bequests to their own children broken down by the educational attainment and wealth quintiles of respondents' households for both Japan and the US. Note that educational attainment in this case refers to that of the respondent or that of his/her spouse, whichever is higher. The figures in Table 3 suggest that betteroff individuals are not only more likely to receive intergenerational transfers from their parents and/or parents-in-law but also more likely to leave bequests to their own children in both Japan and the US. 
Table 3. Incidence of Intergenerational Transfers by Respondents' Living Standard $\%$ of respondents who received $\%$ of respondents who intend or expect to receive bequests to leave bequests

\begin{tabular}{lcccc} 
& \multicolumn{2}{c}{ or expect to receive bequests } & \multicolumn{2}{c}{ to leave bequests } \\
\cline { 2 - 5 } & Japan & US & Japan & US \\
\hline \hline & & & & \\
Educational attainment & & & & \\
$\quad$ Junior high school or lower & 39.11 & 54.17 & 65.92 & 62.50 \\
$\quad$ High school & 58.95 & 57.88 & 72.18 & 76.56 \\
$\quad$ Junior college & 71.14 & 63.89 & 80.35 & 84.03 \\
$\quad$ University or higher & 75.48 & 78.01 & 83.62 & 92.57 \\
& & & & \\
Wealth quintile & 52.15 & 57.04 & 56.12 & 70.17 \\
$1^{\text {st }}$ quintile & 59.75 & 62.56 & 71.07 & 82.16 \\
$2^{\text {nd }}$ quintile & 64.34 & 70.18 & 84.34 & 89.97 \\
$3^{\text {rd }}$ quintile & 72.70 & 78.23 & 87.06 & 95.70 \\
$4^{\text {th }}$ quintile & 81.62 & 81.31 & 91.35 & 97.22 \\
$5^{\text {th }}$ quintile & & & & \\
& & & & \\
Full sample & 65.61 & 69.70 & 77.21 & 86.83 \\
& & & & \\
\hline Number of observations & 2,914 & 1,997 & 2,914 & 1,997 \\
\hline
\end{tabular}

Note: Educational attainment refers to that of the respondent or his/her spouse, whichever is higher. Source: Calculations based on data from the 2010 Preference Parameters Study.

The trends identified in Tables 2 and 3 indicate the possibility that intergenerational transfers have a disequalizing effect on the distribution of wealth. To investigate this possibility more rigorously, we resort to regression analysis.

\subsection{Regression Results}

We begin with the estimation of a seemingly unrelated bivariate probit model for whether or not respondents have a university or higher degree and for whether or not respondents have received or expect to receive bequests and/or inter vivos transfers from their parents. The results for both Japan and the US are reported in terms of average marginal effects in Table 4.

The correlations between the residuals of the two regressions are positive and significant for both Japan and the US, which supports a bivariate probit estimation rather than a separate probit estimation for each type of transfer. The positive correlations between residuals suggest that parents who have invested in the human capital of their children are 
more likely to leave bequests to their children. The signs and statistical significance of the coefficient estimates are broadly similar between these two types of transfers in both Japan and the US, suggesting that the factors influencing parents' decisions regarding investment in their children's education and bequests are relatively similar.

As far as the impact of age is concerned, the coefficients of the age dummies are sometimes significant but there are no clear patterns in either Japan or the US. Women are less likely to have attained a university education in both countries. Women are also less likely to have received or expect to receive bequests and/or inter vivos transfers from their parents in the case of Japan whereas such an effect is not statistically significant in the US. These results are in contrast to the findings of Nordblom and Ohlsson (2011), who find that women are more likely than men to have a university education as well as to receive inter vivos transfers in the case of Sweden. Such differences, particularly in parents' investment in children's education, may reflect the fact that gender equality is greater in Sweden than in Japan or the US, as shown, for example, by the gender inequality index of the United Nations Development Programme (UNDP) (UNDP, 2015).

Table 4. Regression Results for Bivariate Probit Model (average marginal effects)

\begin{tabular}{|c|c|c|c|c|}
\hline & \multicolumn{2}{|c|}{ Japan } & \multicolumn{2}{|c|}{ US } \\
\hline & Education & Bequests & Education & Bequests \\
\hline \multicolumn{5}{|c|}{ Respondents' characteristics } \\
\hline \multicolumn{5}{|c|}{ Age group } \\
\hline \multicolumn{5}{|c|}{ (Less than 35) } \\
\hline \multirow[t]{2}{*}{$35-44$} & -0.013 & 0.040 & $0.317 * * *$ & -0.071 \\
\hline & {$[0.117]$} & {$[0.106]$} & {$[0.116]$} & [0.111] \\
\hline \multirow[t]{2}{*}{$45-54$} & $0.242 * *$ & $0.256^{* *}$ & $0.296 * * *$ & 0.138 \\
\hline & {$[0.116]$} & {$[0.106]$} & {$[0.112]$} & [0.107] \\
\hline \multirow[t]{2}{*}{$55-64$} & 0.184 & $0.346 * * *$ & $0.492 * * *$ & $0.362 * * *$ \\
\hline & {$[0.121]$} & {$[0.108]$} & [0.118] & {$[0.115]$} \\
\hline \multirow[t]{2}{*}{$65+$} & 0.028 & 0.029 & $0.553 * * *$ & $0.200^{*}$ \\
\hline & [0.137] & [0.117] & {$[0.124]$} & {$[0.120]$} \\
\hline \multicolumn{5}{|l|}{ Sex } \\
\hline \multirow[t]{2}{*}{ Female } & $-1.062 * * *$ & $-0.434 * * *$ & $-0.265 * * *$ & -0.047 \\
\hline & {$[0.060]$} & [0.049] & {$[0.061]$} & {$[0.060]$} \\
\hline \multirow{2}{*}{\multicolumn{5}{|c|}{$\begin{array}{l}\text { Race } \\
\text { (White) }\end{array}$}} \\
\hline & & & & \\
\hline \multirow[t]{2}{*}{ Black } & & & -0.172 & $-0.579 * * *$ \\
\hline & & & {$[0.110]$} & [0.101] \\
\hline \multirow[t]{2}{*}{ Others } & & & 0.092 & -0.140 \\
\hline & & & [0.134] & [0.129] \\
\hline
\end{tabular}




\begin{tabular}{|c|c|c|c|c|}
\hline \multicolumn{5}{|l|}{ Family background } \\
\hline Fathers' years of schooling & $\begin{array}{c}0.142^{* * *} \\
{[0.015]}\end{array}$ & $\begin{array}{c}0.011 \\
{[0.013]}\end{array}$ & $\begin{array}{c}0.122 * * * \\
{[0.014]}\end{array}$ & $\begin{array}{c}0.048 * * * \\
{[0.015]}\end{array}$ \\
\hline Mothers' years of schooling & $\begin{array}{c}0.098 * * * \\
{[0.021]}\end{array}$ & $\begin{array}{c}0.053^{* * *} \\
{[0.019]}\end{array}$ & $\begin{array}{c}0.085^{* * *} \\
{[0.018]}\end{array}$ & $\begin{array}{c}0.023 \\
{[0.018]}\end{array}$ \\
\hline Living standard at the age of 15 & $\begin{array}{c}0.086 * * * \\
{[0.016]}\end{array}$ & $\begin{array}{c}0.111^{* * *} * \\
{[0.014]}\end{array}$ & $\begin{array}{c}-0.002 \\
{[0.016]}\end{array}$ & $\begin{array}{c}0.092 * * * \\
{[0.016]}\end{array}$ \\
\hline Number of siblings (current) & & $\begin{array}{c}-0.165^{* * *} \\
{[0.020]}\end{array}$ & & $\begin{array}{c}-0.068 * * * \\
{[0.015]}\end{array}$ \\
\hline Number of siblings (at the age of 15) & $\begin{array}{c}-0.115^{* * *} * \\
{[0.023]}\end{array}$ & & $\begin{array}{c}-0.081^{* * *} \\
{[0.016]}\end{array}$ & \\
\hline$\rho$ & 0.134 & $0.036)$ & 0.174 & $0.039)$ \\
\hline Log likelihood & & & & \\
\hline$\chi^{2}(36)$ for Japan, $\chi^{2}(38)$ for US & & & & \\
\hline Number of observations & & & & \\
\hline
\end{tabular}

Notes: The dependent variable for the Education results is a dummy variable that equals one if respondents obtained a university or higher degree and zero otherwise, and the dependent variable for the Bequests results is a dummy variable that equals one if respondents received or expect to receive bequests and/or inter vivos transfers from their own parents and zero otherwise. ***, **, * denote statistical significance at the $1 \%, 5 \%$, and $10 \%$ levels. Standard errors are shown in parentheses. Regional dummies are included in all regressions.

Source: Estimation based on data from the 2010 Preference Parameters Study.

We included racial dummy variables in the estimation model for the US to examine racial differences. We find that black respondents are less likely to have received or expect to receive bequests and/or inter vivos transfers from their parents than their white counterparts. This is consistent with the findings of the previous literature. Menchik and Jianakoplos (1997), for example, find that white households are more likely to receive inheritances than black households, which helps to explain why the average difference in wealth between black and white households is larger than the average difference in income.

As far as the effects of family background are concerned, we find, as expected, that the more highly educated respondents' fathers are, the higher is the probability that respondents have obtained a university or higher degree and the higher is the probability that they have received or expect to receive bequests and/or inter vivos transfers from their parents in both Japan and the US, though its effect on the probability of respondents' having a university education is not statistically significant in the case of Japan. Similar results are obtained for the effect of the educational attainment of respondents' mothers except that it is not statistically significant in the case of the probability of respondents' 
receiving bequests and/or inter vivos transfers in the US. In addition, the relative standard of living of respondents' families when they were 15 years old is also positively correlated with the incidence of both types of transfers, except that the effect is not statistically significant in the case of the probability of respondents' having obtained a university education in the US. As for the number of siblings, it is negatively correlated with the incidence of both types of transfers in both Japan and the US, as expected.

The results presented in Table 4 thus suggest that wealthier (more highly educated) parents are more likely to invest in the human capital of their children and also more likely to leave bequests and/or inter vivos transfers to their children. This supports our first hypothesis that respondents who receive intergenerational transfers tend to come from better-off families. Moreover, our findings concerning the effects of parental education, the relative standard of living during childhood, and the number of siblings are consistent with the findings of previous studies (e.g., Laitner and Ohlsson, 2001; Menchik and Jianakoplos, 1997; Nordblom and Ohlsson, 2011).

We now turn to the second analysis where the determinants of respondents' intention of leaving bequests to their own children are investigated. Table 5 reports the estimation results of the probit model in terms of average marginal effects for both Japan and the US.

Table 5. Regression Results for Probit Model (average marginal effects)

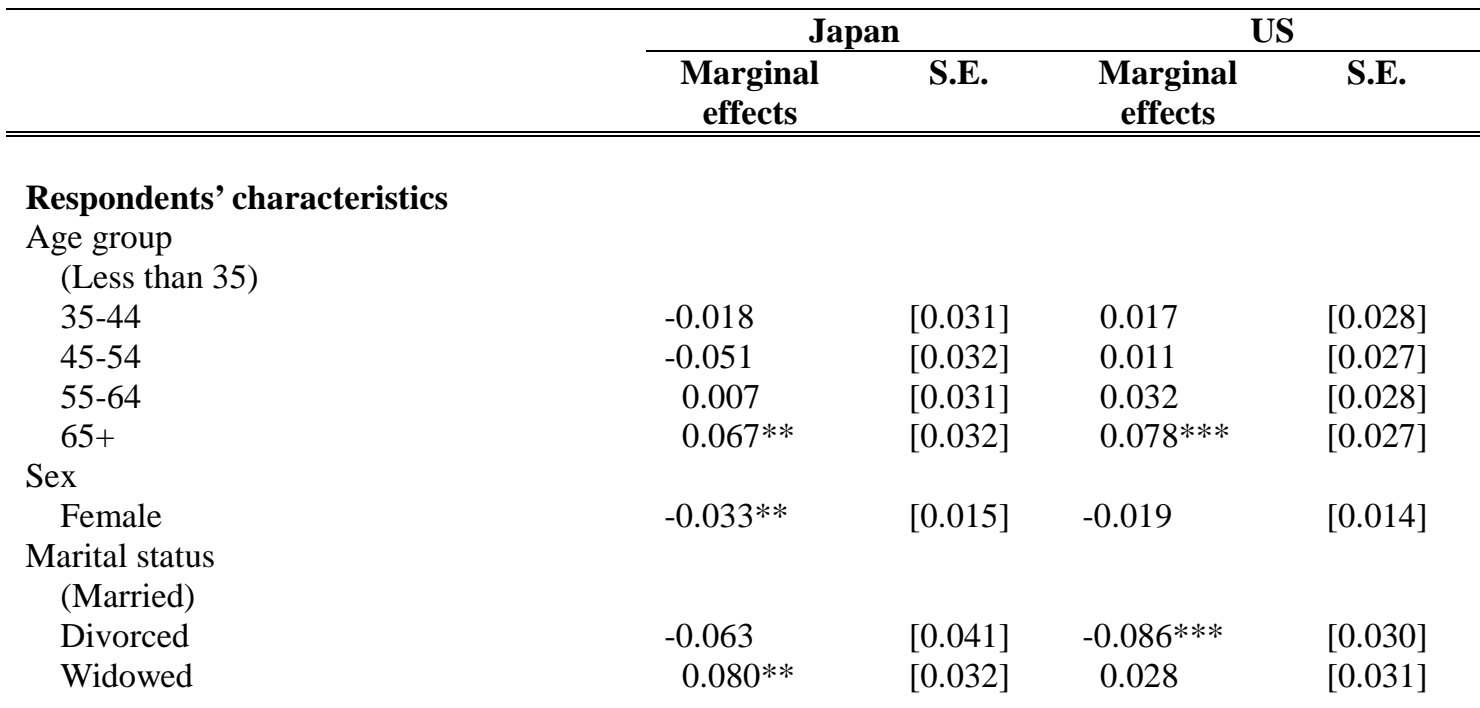




\begin{tabular}{|c|c|c|c|c|}
\hline & \multicolumn{2}{|c|}{ Japan } & \multicolumn{2}{|c|}{ US } \\
\hline & $\begin{array}{c}\text { Marginal } \\
\text { effects }\end{array}$ & S.E. & $\begin{array}{l}\text { Marginal } \\
\text { effects }\end{array}$ & S.E. \\
\hline Never married & $-0.309 * * *$ & [0.115] & $-0.057 * *$ & [0.027] \\
\hline \multicolumn{5}{|l|}{ Race } \\
\hline Black & & & $0.037 *$ & [0.019] \\
\hline Others & & & 0.031 & [0.027] \\
\hline \multicolumn{5}{|l|}{ Preference parameters } \\
\hline Altruism toward children & $0.005^{* * *}$ & {$[0.001]$} & $0.002 * * *$ & [0.001] \\
\hline Low time preference & 0.010 & {$[0.014]$} & 0.020 & [0.015] \\
\hline Risk lover & $0.014^{* * *}$ & {$[0.004]$} & 0.003 & [0.003] \\
\hline \multicolumn{5}{|l|}{ Respondents' household characteristics } \\
\hline Number of children & $-0.017 *$ & [0.009] & $-0.009 *$ & [0.005] \\
\hline $\begin{array}{l}\text { Average years of schooling of respondent } \\
\text { and (if married) spouse }\end{array}$ & $0.018 * * *$ & {$[0.004]$} & $0.015^{* * *}$ & {$[0.004]$} \\
\hline $\begin{array}{l}\text { (Expected) receipt of bequests from } \\
\text { parents and/or parents-in-law }\end{array}$ & $0.108 * * *$ & [0.016] & $0.095 * * *$ & [0.017] \\
\hline \multicolumn{5}{|l|}{ Wealth quintiles } \\
\hline $2^{\text {nd }}$ quintile & $0.105^{* * *}$ & [0.025] & $0.099 * * *$ & [0.026] \\
\hline $3^{\text {rd }}$ quintile & $0.216^{* * *}$ & {$[0.025]$} & $0.148 * * *$ & [0.026] \\
\hline $4^{\text {th }}$ quintile & $0.238 * * *$ & {$[0.024]$} & $0.201 * * *$ & [0.024] \\
\hline $5^{\text {th }}$ quintile & $0.264 * * *$ & {$[0.025]$} & $0.204 * * *$ & [0.025] \\
\hline \multicolumn{5}{|l|}{ (Expected) bequests*wealth } \\
\hline Bequests*2 ${ }^{\text {nd }}$ quintile & $-0.093 *$ & [0.053] & -0.095 & {$[0.060]$} \\
\hline Bequests $* 3^{\text {rd }}$ quintile & $-0.131 * *$ & {$[0.051]$} & -0.057 & [0.059] \\
\hline Bequests $* 4^{\text {th }}$ quintile & $-0.152 * * *$ & {$[0.051]$} & $-0.177 * * *$ & [0.052] \\
\hline Bequests $* 5^{\text {th }}$ quintile & $-0.132 * *$ & {$[0.052]$} & $-0.160 * * *$ & [0.052] \\
\hline Pseudo $\mathrm{R}^{2}$ & \multicolumn{2}{|c|}{0.153} & \multicolumn{2}{|c|}{0.187} \\
\hline Log likelihood & \multicolumn{2}{|c|}{$-1,324.07$} & \multicolumn{2}{|c|}{-632.90} \\
\hline$\chi^{2}$ (31) for Japan, $\chi^{2}$ (32) for US & \multicolumn{2}{|c|}{479.65} & \multicolumn{2}{|c|}{290.26} \\
\hline Number of observations & \multicolumn{2}{|c|}{2,914} & \multicolumn{2}{|c|}{1,997} \\
\hline
\end{tabular}

S.E. = standard errors

Notes: The dependent variable is a dummy variable that equals one if respondents intend to leave bequests to their own children and zero otherwise. ***, **, * denote statistical significance at the 1\%, 5\%, and $10 \%$ levels. Regional dummies are included in all regressions.

Source: Estimation based on data from the 2010 Preference Parameters Study.

We find that those who are aged 65 or above are more likely to leave bequests to their children in both Japan and the US than those aged less than 35 years old. Women are less likely to leave bequests to their children in Japan. Being divorced or never married reduces the probability of leaving bequests while being widowed increases it in both countries, though the statistical significance of these effects varies between the two countries. The positive effect of being widowed on the probability of leaving bequests might be due to the fact that some of those who are married consider leaving bequests to their spouses first, as a result of which married people are less likely to leave bequests to 
their children than widowed people. As expected, those who are more altruistic toward their children are more likely to leave bequests to them in both Japan and the US, suggesting that bequests are altruistically motivated in both countries.

As for the effects of the characteristics of respondents' households, the number of children is negatively associated with the probability of leaving bequests. In addition, the more highly educated respondents and their spouses are, the more likely they are to leave bequests to their own children. These findings are consistent with the findings of the first analysis where we found that people are more likely to receive intergenerational transfers if they have relatively highly educated parents or if they have fewer siblings.

What about the impact of receiving intergenerational transfers from parents or parentsin-law on respondents' bequest behavior (i.e., the intergenerational correlation of bequest propensities)? As expected, the estimation results show a positive effect: the (expected) receipt of intergenerational transfers from their parents or parents-in-law increases the probability of respondents' leaving bequests to their own children by 11 percentage points and 10 percentage points in Japan and the US, respectively. In other words, if respondents have received or expect to receive intergenerational transfers from their parents and/or parents-in-law, they are more likely to leave bequests to their own children, confirming our second hypothesis. The marginal effects of wealth quintiles also suggest that, as expected, wealthier individuals are more likely to leave bequests to their children. For example, moving from the lowest to the highest wealth quintile increases the probability of respondents' leaving bequests to their children by 26 percentage points and 20 percentage points in Japan and the US, respectively.

We also wanted to examine whether the intergenerational correlation of bequest propensities is greater among wealthier households. We therefore included interaction terms between wealth quintile dummies and the dummy variable for the (expected) receipt of intergenerational transfers from parents and/or parents-in-law. The negative marginal effects of these interaction terms suggest that the tendency for bequest behavior to be similar between parents and children is, in fact, relatively strong in the least wealthy 
quintile. In other words, the difference in the probability of respondents' leaving bequests to their children between those receiving and not receiving intergenerational transfers is smaller for relatively high wealth quintiles than for the lowest wealth quintile both in Japan and the US. These results thus reject our third hypothesis that the tendency for bequest behavior to be similar between parents and children is stronger for better-off households.

Our finding of a higher intergenerational correlation of bequest propensities among less wealthy households might reflect the fact that the poor need to rely more on intergenerational transfers from their parents and/or parents-in-law to be able to accumulate enough wealth to pass on to their own children whereas relatively wealthy people are capable of raising sufficient wealth to leave to their children regardless of whether or not they receive intergenerational transfers from their parents or parents-inlaw.

To summarize, this paper looked specifically at whether or not individuals who receive bequests and/or inter vivos transfers from their parents are more likely to leave bequests to their children than those who do not receive such transfers as a way of examining the role of intergenerational transfers in shaping the distribution of wealth. Our estimation results indeed suggest that the (expected) receipt of intergenerational transfers enhances the likelihood of leaving a bequest to one's own children.

On the other hand, the negative marginal effects of the interaction terms between the receipt of intergenerational transfers and wealth quintiles suggest that the intergenerational correlation of bequest propensities is greater among relatively less welloff households. According to the estimation results, the poor are more likely to mimic their parents' bequest behavior than the rich and receiving intergenerational transfers from their parents and/or parents-in-law increases the poor's likelihood of leaving bequests to their children by more than in the case of the rich. Such a tendency may help attenuate the disequalizing effect of intergenerational transfers on the distribution of wealth, at least to some extent. These findings seem to be consistent with the findings of previous 
empirical work based on household survey data that intergenerational transfers help reduce relative inequality even though they might widen absolute inequality (e.g., Elinder, Erixson and Waldenström, 2016; Karagiannaki, 2015).

Nevertheless, our findings also show that those who receive intergenerational transfers from their parents tend to come from better-off families and that wealthier individuals are more likely to leave bequests to their children than less wealthy ones. These findings seem to underscore the possibility that intergenerational transfers contribute to the passing on of wealth disparities from generation to generation.

We were also interested in comparing the cases of Japan and the US in this paper because of the large difference in wealth inequality between Japan and the US, with the latter showing a much larger dispersion of household wealth, as noted earlier. It is therefore somewhat surprising that the Japanese and Americans seem to exhibit similar bequest patterns in terms of the intergenerational correlation of bequest propensities. We thus need to resort to other factors to explain the greater inequality of wealth in the US than in Japan. One possible explanation is that the incidence of intergenerational transfers is greater in the US than in Japan, as our data suggest. We found that the proportion of respondents having received or expecting to receive intergenerational transfers as well as the proportion of respondents intending to leave bequests were both larger among Americans than among the Japanese. Hence, it could be that wealth inequality is higher in the US than in Japan, even though the intergenerational correlation of bequest propensities is comparable in the two countries, because the propensity to bequeath itself is higher in the US than in Japan.

Another possibility is that the strength and nature of bequest motives differs between Japan and the US, as pointed out by Horioka (2014). Our data show that only about 24\% of Japanese respondents plan to leave bequests no matter what or under certain conditions whereas $54 \%$ of US respondents plan to do so. By contrast, $49 \%$ of Japanese respondents do not plan to make special efforts to leave bequests but plan to leave whatever is left over to their children whereas this proportion is only $31 \%$ in the US. In other words, 
accidental or involuntary bequests might be more common than voluntary bequests in Japan. This may partly explain why wealth inequality is lower in Japan than it is in the US because, as De Nardi (2004) finds based on a general equilibrium, overlappinggenerations model, accidental or involuntary bequests are less likely to contribute to the concentration of wealth than voluntary bequests.

Furthermore, the fact that the burden of bequest (inheritance or estate) taxes is higher in Japan than it is in the US may also help explain the greater inequality of wealth in the US than in Japan. Since January 1, 2015, the minimum taxable bequest in Japan has been 30 million yen (0.30 million US dollars, assuming an exchange rate of 100 yen per US dollar) plus 6 million yen (0.06 million US dollars) times the number of statutory heirs. Thus, if there are three statutory heirs (for example, the decedent's spouse and two children), the minimum taxable bequest would be 48 million yen (0.48 million US dollars). By contrast, the minimum taxable bequest in the US as of 2016 is 5.45 million US dollars or more than 10 times the Japanese figure. As a result, the proportion of decedents liable for bequest taxes is more than $4 \%$ in Japan but only $0.2 \%$ in the US. ${ }^{12}$

Moreover, the tax rate of the bequest tax is also much higher in Japan (a maximum rate of 55\% in Japan vs. $40 \%$ in the US), and "will substitutes" (bequest tax loopholes) such as irrevocable living trusts are less readily available in Japan than in the US (see Hamaaki, Hori and Murata (2016) for more details). The most comprehensive measure of the relative importance of bequest taxes is the ratio of estate, inheritance, and gift tax to GDP, and as Niimi (2016) shows, this percentage is about twice as high in Japan as it is in the US ( $0.36 \%$ in Japan vs. $0.15 \%$ in the US in 2014$)$. Hence, by any measure, the burden of bequest taxes is much heavier in Japan than it is in the US. This could be one reason why we observe greater wealth inequality in the US than in Japan and may also help explain why the bequest motive of the Japanese generally tends to be weaker than that of Americans.

\footnotetext{
12 The proportions of decedents liable for bequest taxes in each country are taken from Ministry of Finance, Government of Japan (https://www.mof.go.jp/tax_policy/summary/property/137.htm, accessed on April 4, 2016) for Japan and from Joint Committee on Taxation, Congress of the United States (https://www.jct.gov/publications.html?func=startdown\&id=4, accessed on July 17, 2016) for the US.
} 


\section{Conclusions}

This paper has made an attempt to examine the implications of intergenerational transfers for wealth inequality. More specifically, it has investigated whether or not individuals who receive intergenerational transfers from their parents are more likely to leave bequests to their children than those who do not receive such transfers using data on Japan and the US. We found that the (expected) receipt of intergenerational transfers increases the probability of respondents' leaving bequests to their own children in both countries. The observed similarity in bequest behavior between parents and children suggests the possibility that wealth disparities are passed on from generation to generation, contributing to the persistence or widening of wealth disparities, in both countries.

If the tendency for bequest behavior to be similar between parents and children is stronger among better-off households, this would exacerbate the situation even further. However, we found that this tendency was, in fact, stronger among less better-off households in both countries. In other words, receiving intergenerational transfers from their parents and/or parents-in-law increases the poor's likelihood of leaving bequests to their children by more than in the case of the rich.

On the other hand, the estimation results show that, in both Japan and the US, the wealthier respondents' parents are, the more likely respondents are to have received a university education (i.e., the more likely parents are to have invested in their children's human capital) and the more likely respondents are to have received or expect to receive intergenerational transfers from their parents. We also found that wealthier respondents are more likely to leave bequests to their own children. These results imply that intergenerational transfers are likely to contribute to the persistence or widening of wealth disparities from generation to generation.

However, our analysis is not without its caveats. Due to data limitations, we were able to look only at the probability of receiving and leaving intergenerational transfers and were 
not able to look at the amounts of such transfers in the present study, as noted earlier. To fully examine the implications of intergenerational transfers for wealth inequality, further analysis taking account of the amount of wealth transfers is required. Moreover, as in the case of many other household surveys, very wealthy households may be underrepresented in the survey used for this paper. A more detailed analysis focusing on the upper tail of the wealth distribution may help us to better understand the role of intergenerational transfers in shaping the distribution of wealth.

Nevertheless, this paper is one of the first to examine the intergenerational correlation of bequest propensities and to show, at least qualitatively, that intergenerational transfers are likely to contribute to the persistence or widening of wealth disparities both in Japan and the US. The paper, though, also shows that the tendency of bequest behavior to be similar between parents and children is stronger among less better-off households in both countries, which may help alleviate the disequalizing effect of intergenerational transfers on the distribution of wealth, at least to some extent.

Turning finally to the policy implications of the empirical analysis conducted in this paper, our finding that wealth inequality is likely to be passed on from generation to generation both in Japan and the US suggests the need to raise bequest tax rates, lower the amount of the minimum taxable bequest, and/or close bequest tax loopholes to alleviate the extent to which wealth disparities are passed on from generation to generation. Moreover, the fact that wealth is more unequally distributed in the US than in Japan suggests that the need for such policies may be greater in the US than in Japan. ${ }^{13}$

\footnotetext{
13 However, it should be borne in mind that bequest taxes may have undesirable side effects such as weakening the saving incentives of parents.
} 


\section{References}

Atkinson, A. B. (1971), “The Distribution of Wealth and the Individual Life-Cycle," Oxford Economic Papers, 23(2), pp. 239-254.

Becker, G. S. and N. Tomes (1986), "Human Capital and the Rise and Fall of Families," Journal of Labor Economics, 4(3), pp. S1-S39.

Bossmann, M., C. Kleiber and K. Wälde (2007), “Bequests, Taxation and the Distribution of Wealth in a General Equilibrium Model,” Journal of Public Economics, 91(7-8), pp. 1247-1271.

Charles, K. K. and E. Hurst (2003), "The Correlation of Wealth across Generations," Journal of Political Economy, 111(6), pp. 1155-1182.

Cox, D. and O. Stark (2005), "Bequests, Inheritances and Family Traditions,” CRR Working Papers, No. 2005-9, Chestnut Hill: Center for Retirement Research at Boston College.

Davies, J. B. (1981), “Uncertain Lifetime, Consumption, and Dissaving in Retirement," Journal of Political Economy, 89(3), pp.561-577.

Davies, J. B. (1982), “The Relative Impact of Inheritance and Other Factors on Economic Inequality,” Quarterly Journal of Economics, 97(3), pp. 471-498.

Davies, J. B., S. Sandström, A. Shorrocks and E. N. Wolff (2011), "The Level and Distribution of Global Household Wealth,” Economic Journal, 121(551), pp. 223254

Davies, J. B. and A. F. Shorrocks (2000), “The Distribution of Wealth,” in Atkinson, A. B. and F. Bourguignon (eds.) Handbook of Income Distribution. Vol. 1, Oxford: Elsevier.

De Nardi, M. (2004), "Wealth Inequality and Intergenerational Links," Review of Economics Studies, 71(3), pp. 743-768.

Elinder, M., O. Erixson and D. Waldenström (2016), "Inheritance and Wealth Inequality: Evidence from Population Registers,” IZA Discussion Paper, No. 9839, Bonn: Institute for the Study of Labor.

Gokhale, J., L. J. Kotlikoff, J. Sefton and M. Weale (2001), “Simulating the Transmission of Wealth Inequality via Bequests,” Journal of Public Economics, 79(1), pp. 93-128.

Hamaaki, J., M. Hori, and K. Murata (2016), “The Intra-Family Division of Bequests and 
Bequest Motives: Empirical Evidence from a Survey on Japanese Households,” mimeo., Faculty of Economics, Hosei University, Tokyo, Japan.

Horioka, C. Y. (2014), “Are Americans and Indians More Altruistic than the Japanese and Chinese? "Evidence from a New International Survey of Bequest Plans,” Review of Economics of the Household, 12(3), pp. 411-437.

Horioka, C. Y. (2016), “The Impact of Intergenerational Transfers on the Distribution of Wealth: An International Comparison,” mimeo., Kitakyushu: Asian Growth Research Institute.

Karagiannaki, E. (2015), "The Impact of Inheritance on the Distribution of Wealth: Evidence from Great Britain," Review of Income and Wealth, doi: 10.1111/roiw.12217.

Klevmarken, N. A. (2004), "On the Wealth Dynamics of Swedish Families, 1984-98," Review of Income and Wealth, 50(4), pp. 469-491.

Kotlikoff, L. J. and L. H. Summers (1981), “The Role of Intergenerational Transfers in Aggregate Capital Accumulation,” Journal of Political Economy, 89(4), pp. 706-732.

Laitner, J. and H. Ohlsson (2001), "Bequest Motives: A Comparison of Sweden and the United States,” Journal of Public Economics, 79(1), pp. 205-236.

Menchik, P. L. and N. A. Jianakoplos (1997), "Black-White Wealth Inequality: Is Inheritance the Reason?” Economic Inquiry, 35(2), pp. 428-442

Modigliani, F. (1988), “The Role of Intergenerational Transfers and Life Cycle Saving in the Accumulation of Wealth,” Journal of Economic Perspectives, 2(2), pp. 15-40.

Modigliani, F. and R. Brumberg (1954), "Utility Analysis and the Consumption Function: An Interpretation of Cross-section Data,” in Kurihara, K. K. (ed.) Post-Keynesian Economics, New Brunswick: Rutgers University Press.

Nordblom, K. and H. Ohlsson (2011), "Bequests, Gifts, and Education: Links between Intergenerational Transfers,” Empirical Economics, 40(2), pp. 343-358.

Niimi, Y. (2016), “To Avoid or Not to Avoid Inheritance Taxes? That Is the Question for Parents: Empirical Evidence from Japan”, AGI Working Paper Series, No. 2016-13, Kitakyushu: Asian Growth Research Institute.

Organisation for Economic Co-operation and Development (OECD) (2015), In It Together: Why Less Inequality Benefits All, Paris: OECD Publishing.

Oulton, N. (1976), "Inheritance and the Distribution of Wealth,” Oxford Economic Papers, 28(1), pp. 86-101. 
Piketty, T. (2011), “On the Long-run Revolution of Inheritance: France 1820-2050,” Quarterly Journal of Economics, 126(3), pp. 1071-1131.

Piketty, T. (2014), Capital in the Twenty-First Century, Cambridge and London: Belknap Press of Harvard University Press.

Saez, E. and G. Zucman (2016), "Wealth Inequality in the United States since 1913: Evidence from Capitalized Income Tax Data,” Quarterly Journal of Economics, doi: 10.1093/qje/qjw004.

United Nations Development Programme (UNDP) (2015), Human Development Report 2015: Work for Human Development, New York: UNDP.

Wolff, E. N. (2002), “Inheritances and Wealth Inequality, 1989-1998," American Economic Review, 92(2), pp. 260-264.

Yaari, M. E. (1965), "Uncertain Lifetime, Life Insurance, and the Theory of the Consumer,” Review of Economics Studies, 32(2), pp. 137-150. 